Notes

\title{
Spectrophotometric Determination of Aluminum with $m$-Carboxyphenylfluorone, a Novel Chemical Probe, and Its Application
}

\author{
Shinichiro Kamino, ${ }^{\dagger}$ Takako Yamaguchi, Terumi Mori, Mika MiYamoto, Yukimi Kusumi, and \\ Yoshikazu FuJITA
}

Osaka University of Pharmaceutical Sciences, 4-20-1 Nasahara, Takatsuki, Osaka 669-1094, Japan

\begin{abstract}
A highly spectrophotometric method for the determination of aluminum was developed. This method used the color reaction between $m$-carboxyphenylfluorone (MCPF) as a novel chemical probe and aluminum in the presence of a surfactant, poly( $N$-vinylpyrrolidone) (PVP, K-90) $(0.03-1.40 \mu \mathrm{g}$ of aluminum in a final volume of $10 \mathrm{ml}$ at $561 \mathrm{~nm})$. The proposed method showed excellent sensitivity (molar absorptibity of $1.70 \times 10^{5} 1 \mathrm{~mol}^{-1} \mathrm{~cm}^{-1}$ ) and reproducibility (within-day precision: $\mathrm{RSD}=0.35 \% n=6$, between-day precision: $\mathrm{RSD}=0.44 \% n=6$ ). Linearity was achieved over the range $3-140 \mu \mathrm{g} \mathrm{L}{ }^{-1}$ with a correlation coefficient of 0.9999 , and the effects of foreign substances were low.
\end{abstract}

(Received June 27, 2005; Accepted October 3, 2005)

\section{Introduction}

Aluminum is recognized as an important toxic substance ${ }^{1-5}$ causing considerable morbidity and mortality in humans. Dialysis dementia, renal osteodystrophy and Alzheimer's disease have been associated with exposure in medical treatment and excess intake of pharmaceuticals containing aluminum, which indicates the importance for internal aluminum monitoring. Since the occurrence of dialysis dementia in the $1970 \mathrm{~s},{ }^{6}$ the measurement of aluminum in serum routinely has been carried out in medical institution. This is why a simple, rapid, and highly sensitive method for the assay of aluminum is required.

Generally, atomic absorption spectrometry (AAS) ${ }^{7-10}$ and inductively coupled plasma atomic emission spectrometry (ICP$\mathrm{AES})^{11}$ are the most commonly used techniques in the determination of trace level aluminum. These methods present difficulties in speciation analysis in addition to being costly. Spectrophotometry, however, continues to enjoy wide populality. While there are many methods that use color reaction systems in spectrophotometry: 8-hydroxyquinoline method, ${ }^{12}$ Chrome Azurol S method, ${ }^{13}$ dihydroxyazobenzene method, ${ }^{14}$ and Methylthymol Blue method, ${ }^{15}$ most of them are not satisfactory, showing poor convenience, low sensitivity, low reproducibility and effects of interferents. Even so, spectrophotometry has become the most widely used detection technique because of its speed, precision, accuracy, and costeffectiveness.

Xanthene dyes such as phenylfluorone and fluorescein are the oldest synthetic dyes; they are widely used as powerful probes for the determination of several biological substances. Many reports have applied a complex system between a xanthene dye

$\dagger$ To whom correspondence should be addressed.

E-mail: d05001@gly.oups.ac.jp

A part of this work was prepared at the 52th Annual Meeting of the Japan Society for Analytical Chemistry, Sendai, 2003. and a metal to simple and sensitive spectrophotometric determinations of various metals. ${ }^{16-19}$ Here, we novely synthesized $m$-carboxyphenylfluorone (MCPF) as a chemical probe, which is the phenylfluorone (PF) derivatives that provide high metal ion complex-forming abilities, and investigated the coloring systems among MCPF, aluminum(III), and various surfactants in weakly basic media. Consequently, we have been developed a novel, simple, highly sensitive, and rapid spectrophotomeric determination of aluminum(III) by using color reaction between MCPF and aluminum in the presence of a nonionic surfactant: $\operatorname{poly}(N$-vinylpyrrolidone) (PVP-90). This proposed method was then applied to assay the aluminum in pharmaceutical preparations. In addition, the recovery tests of aluminum(III) in human urine, bovine serum and tap water were investigated.

\section{Experimental}

\section{Apparatus and reagents}

Absorption spectra and absorbance were measured on a Shimadzu UV-160A spectrophotometer with $10 \mathrm{~mm}$ quartz cells. A HORIBA F-11 glassware $\mathrm{pH}$ meter was used for the $\mathrm{pH}$ measurements. An ASONE TR-2A Heating bath was used for the reaction. NALGENE polypropylene vessels and testtubes were used. In order to prevent contamination, we prepared all pieces of glassware by immersion for $24 \mathrm{~h}$ in 20 $\mathrm{v} / \mathrm{v} \%$ nitric acid, rinsing in de-ionized water and drying in a dust-free cabinet.

Care was taken in sample storage, reagent preparation and pretreatment of equipment in order to prevent contamination. A $2.0 \times 10^{-4} \mathrm{M}$ solution of MCPF was prepared in methanol containing one drop of $20 \mathrm{v} / \mathrm{v} \% \mathrm{HCl}$. In a quartz vessel to prevent contamination, an aluminum(III) solution was carefully in water by $20 \mathrm{v} / \mathrm{v} \% \mathrm{HCl}$ treatment of aluminum plate (99.99\%), purchased from Wako Pure Chemical Co. Ltd. A 1.5 w/v\% solution of poly( $N$-vinylpyrrolidone) (PVP K-90) (Nacalai Tesque) was prepared in water. A buffer solution of 


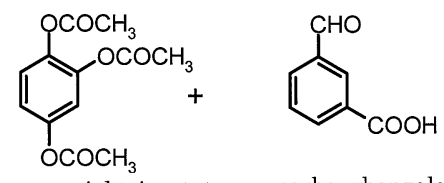

1,2,4-benzentriol triacetate $m$-carboxybenzaledehyde

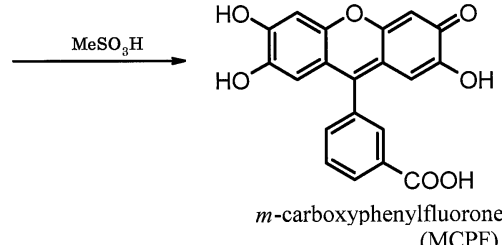

(MCPF)

Fig. 1 Synthesis scheme of $m$-carboxyphenylfluorone (MCPF).

pH 9.0 was prepared by mixing $0.2 \mathrm{M} \mathrm{HCl}$ and $0.2 \mathrm{M} 2$-amino2-(hydroxymethyl)-1,3-propanediol (Tris) solution. All other reagents and materials were of analytical grade, and were used without further purification. Pure water was prepared by purifying deionized water with a Milli-Q Labo System just before use.

\section{Synthetic procedure: m-carboxyphenylfluorone (Fig. 1)}

1,4-Benzoquinone $(10.0 \mathrm{~g}, 92.5 \mathrm{mmol})$ following the literature ${ }^{20}$ was dissolved in $20 \mathrm{ml}$ of acetic anhydride and $2 \mathrm{ml}$ of sulfuric acid at $40-50^{\circ} \mathrm{C}$. After cooling, the reaction mixture was poured into $50 \mathrm{ml}$ water, affording a white precipitate that was filterd and washed with water. $m$-Carboxyphenylfluorone (MCPF) was synthesized from condensation with $\mathrm{MeSO}_{3} \mathrm{H}$ between 1,2,4-benzentriol triacetate $(5.0 \mathrm{~g}, 21.9 \mathrm{mmol})$ and $\mathrm{m}$ carboxybenzaldehyde $(1.6 \mathrm{~g}, 11.0 \mathrm{mmol})$, and the reaction was heated to reflux for $80 \mathrm{~h}$ causing the orange precipitate. The product was purified by dissolving in methanol. Pure MCPF was obtained in 43.0\%: MS[SIMS: $m / z=365] ;{ }^{1} \mathrm{H}-$ NMR(DMSO- $\left.d_{6}\right) \delta 8.19(1 \mathrm{H}, \mathrm{dt}, J=7.8,1.6), 7.95(1 \mathrm{H}, \mathrm{t}, J=$ 1.6), $7.81(1 \mathrm{H}, \mathrm{t}, J=7.8),, 7.72(1 \mathrm{H}, \mathrm{dt}, J=7.8,1.6), 6.73(2 \mathrm{H}$, $\mathrm{s}), 6.33(2 \mathrm{H}, \mathrm{s})$.

\section{Standard procedure for the determination of aluminum}

The following components were mixed in a $10 \mathrm{ml}$ polypropylene volumetric flask: $3.0 \mathrm{ml}$ of the buffer solution, $2.5 \mathrm{ml}$ of a PVP solution, $2.0 \mathrm{ml}$ of a $2.0 \times 10^{-4} \mathrm{M} \mathrm{MCPF}$ solution, and a solution containing from $0.03 \mu \mathrm{g}$ to $1.4 \mu \mathrm{g}$ of aluminum(III). The mixture was then made up to volume with water, transferred into a polypropylene test tube, mixed well and kept at room temperature for $10 \mathrm{~min}$. Then the absorbance of the resultant solution (Solution A) was measured at $561 \mathrm{~nm}$ against a reagent blank prepared in the same way (Solution B)

\section{Results and Discussion}

\section{Optimization of the conditions and absorption spectra}

The effects of various buffer solutions and $\mathrm{pH}$ values on color development were investigated by using Tris- $\mathrm{HCl}, \mathrm{NH}_{3}-\mathrm{NH}_{4} \mathrm{Cl}$, glycine- $\mathrm{NaOH}, \quad 2$-( $N$-cyclohexylamino)ethanesulfonic acid (CHES)-NaOH, $\quad \mathrm{Na}_{2} \mathrm{~B}_{4} \mathrm{O}_{7}-\mathrm{Na}_{2} \mathrm{CO}_{3}, \quad \mathrm{Na}_{2} \mathrm{~B}_{4} \mathrm{O}_{7}-\mathrm{NaOH}, \quad$ Bis tris propane- $\mathrm{HCl}, \mathrm{Na}_{2} \mathrm{CO}_{3}-\mathrm{NaHCO}_{3}$, and $\mathrm{H}_{3} \mathrm{BO}_{3}-\mathrm{KCl}-\mathrm{Na}_{2} \mathrm{CO}_{3}$. The maximum and constant absorbance value was obtained in the $\mathrm{pH}$ range of 8.7 to 9.2 with $3.0 \mathrm{ml}$ of $0.2 \mathrm{M}$ Tris- $0.2 \mathrm{M} \mathrm{HCl}$ buffer solutions.

For the purpose of sensitization by micellar systems, various surfactants were tested. Nonionic surfactants: $\operatorname{poly}(N-$ vinylpyrrolidone) (K-15, 30, 90), polyvinylalcohol (PVA),

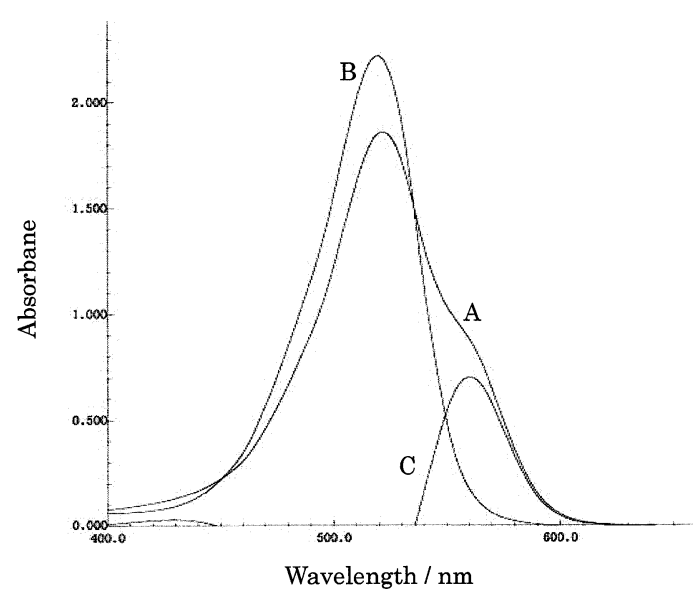

Fig. 2 Absorption spectra. Al(III) ion, $88 \mu \mathrm{g} \mathrm{L}^{-1}$; PVP, 0.15\%; $\mathrm{pH}$, 9.0; $\mathrm{MCPF}, 2.0 \times 10^{-5} \mathrm{M}$; Curve A, Al(III)-MCPF solution; curve B, MCPF solution; curve $C$, curve A minus curve B.

polyethylene glycol mono- $p$-isooctylphenyl ether (Triton X100), polyoxyethylene sorbitan monostearate (Tween 20), polyoxyethylene lauryl ether (Brij35). Cationic surfactants: hexadecyltrimethyl ammonium chloride (HTAC), hexadecylpyridium chloride (HPC), hexadecylstearylammonium chloride (HSAC), Zephiramine. Anionic surfactants: sodium dodecylsulfate (SDS), di-2-ethylhexyl sodium sulfosuccinate (AOT). Amphoteric surfactants: 1dodecanaminium $\quad N$-(carboxymethyl)- $N, N$-dimethyl, inner $\operatorname{salt}(9 \mathrm{Cl})$ (Swanol AM-301). The presence of a nonionic surfactant such as polyvinylpyrrolidone gave the maximum and constant absorbance, and the absorption maximum showed a small red shift. Above all, no less than $2.0 \mathrm{ml}$ of $1.5 \mathrm{w} / \mathrm{v} \%$ PVP K-90 against total $10 \mathrm{ml}$ was most effective.

The effects of the amounts of MCPF were examined. The maximum constant absorbance value was observed when more than $2.0 \mathrm{ml}$ of $2.0 \times 10^{-4} \mathrm{M}$ MCPF was added.

When the influence of the sequence of adding the reagents on the absorbance values was studied, buffer solution $\rightarrow$ PVP $\rightarrow$ $\mathrm{MCPF} \rightarrow$ aluminum(III) solution showed the best performance.

The color development in this reaction system occurred instantaneously at room temperature. The effects of the incubation temperatures and times comparing with room temperature conditions were examined by heating for $10-60$ min at various temperatures $\left(40^{\circ} \mathrm{C}, 50^{\circ} \mathrm{C}\right.$, and $\left.60^{\circ} \mathrm{C}\right)$ for the purpose of improvement in sensitivity and reproducibility. The behavior by heating, however, had no effect on these qualities. The stability of the absorbance value of the resulting Solution A continued to be stable between $15 \mathrm{~min}-24 \mathrm{~h}$.

Figure 2 shows the absorption spectra of Solutions A and B under the standard procedure. The absorption maximum of Solution B $\left(\lambda_{\max }: 530 \mathrm{~nm}\right)$ gradually exhibited a red shift with increasingly aluminum(III) concentrations, and a distinct difference in the absorbance between Solutions A and B was observed at around $561 \mathrm{~nm}$.

\section{Calibration curve}

The calibration curve was linear for aluminum concentrations ranging from 3 to $140 \mu \mathrm{g} \mathrm{L}^{-1}$. The apparent molar absorptivity $(\varepsilon)$ was calculated from the slope of the calibration graph to be $1.70 \times 10^{5} \mathrm{1} \mathrm{mol}^{-1} \mathrm{~cm}^{-1}$ and the correlation coefficient was $r=$ 0.9999 . This procedure is much more sensitive than other spectrophotometric methods. Table 1 indicates the comparison of sensitivities based several methods. 
Table 1 Comparison of sensitivity with other methods of assay for aluminum

\begin{tabular}{lcc}
\hline \multicolumn{1}{c}{ Method } & $\begin{array}{c}\text { Apparent molar absorptivity } \\
\varepsilon / 1 \mathrm{~mol}^{-1} \mathrm{~cm}^{-1}\end{array}$ & Ref. \\
\hline This method & $1.7 \times 10^{5}$ & \\
8-Hydroxyquinoline method & $7.3 \times 10^{3}$ & 12 \\
Chrome Azurol S method & $1.1 \times 10^{5}$ & 13 \\
DHAB method & $3.7 \times 10^{4}$ & 14 \\
Methylthymol Blue method & $1.9 \times 10^{4}$ & 15 \\
Extractive xylene method & $1.7 \times 10^{5}$ & 21 \\
\hline
\end{tabular}

Table 2 Difference of reproducibilities by elimination of the contamination of aluminum in several vessels

\begin{tabular}{ccl}
\hline Treatment & \multicolumn{2}{c}{ Relative standared deviation (RSD), \% } \\
\hline (A) & 3.43 & $(n=6:$ within-day precision $)$ \\
(B) & 1.48 & $(n=6:$ within-day precision $)$ \\
(C) & 0.35 & $(n=6:$ within-day precision $)$ \\
& 0.44 & $(n=6:$ between-day precision $)$ \\
\hline
\end{tabular}

(A) Glassware use; (B) glassware use all pieces were prepared by immersion for $24 \mathrm{~h}$ in $20 \mathrm{v} / \mathrm{v} \%$ nitric acid, rinsing in deionized water and drying a dust-free cabinet; (C) polypropylene use all pieces were prepared by immersion for $24 \mathrm{~h}$ in $20 \mathrm{v} / \mathrm{v} \%$ nitric acid, rinsing in deionized water and drying a dust-free cabinet; $\mathrm{Al}(\mathrm{III})$ added: $50 \mu \mathrm{g}$ $\mathrm{L}^{-1}$.

In the determination of aluminum(III), we must pay attention to the prevention of contamination..$^{21,22}$ Polypropylene was treated by immersion for $24 \mathrm{~h}$ in $20 \mathrm{v} / \mathrm{v} \%$ nitric acid, rinsing in de-ionized water and drying in a dust-free cabinet [RSD = $0.35 \%$ ( $n=6$ : within-day precision $), \operatorname{RSD}=0.44 \%(n=6$ : between-day precision)]. The results shown in Table 2 suggested that it was essential to select suitable vessels and treatment conditions during the assay of aluminum(III).

This proposed method has the following advantages: (1) higher sensitivity than conventional methods, (2) wider linear part in the calibration curve, and (3) excellent reproducibility both within-day and between-day precision.

\section{Interference of foreign substances}

The influence of various foreign substances on the determination of aluminum(III) was examined. Small amounts (less than about 10-fold) of zinc(II), iron(II), copper(II), magnesium(II) and iron(III) caused positive errors and antimony(III) caused negative errors. On the other hand, large amounts of ascorbic acid and potassium, sodium, chloride, phosphate, carbonate, sulfate, acetate, nitrate, fluoride, sulfide, bromide, ammonium, citrate, tartrate, or oxalate ions did not interfere with the determination of aluminum(III). The presence of urea, creatinine, glycine, glucose, DNA, or thiamine as biological substances also did not interfere. Uric acid caused minor errors. The effects of zinc(II), copper(II), iron(II), and iron(III) could be depressed by addition of potassium cyanide and sodium ascorbate as masking agents. The masking agent of antimony(III) was not examined. The results are summarized in Table 3.

\section{Application}

In order to validate the proposed method we applied it to the determination of aluminum(III) in commercial pharmaceutical preparation (tablets). An appropriate amount of the sample
Table 3 Effect of foreign substances and selection of masking agents on aluminum(III)

\begin{tabular}{|c|c|c|c|}
\hline $\begin{array}{c}\text { Substance } \\
\text { (+ Masking reagent) }\end{array}$ & $\begin{array}{c}\text { Molar ratio } \\
\text { (Substance/Al) }\end{array}$ & $\begin{array}{l}\text { Absorbance } \\
\text { at } 561 \mathrm{~nm}\end{array}$ & $\begin{array}{c}\text { Recovery, } \\
\%\end{array}$ \\
\hline None & - & 0.340 & 100.0 \\
\hline $\mathrm{K}(\mathrm{I})$ & 1000 & 0.340 & 100.0 \\
\hline $\mathrm{Na}(\mathrm{I})$ & 1000 & 0.340 & 100.0 \\
\hline $\mathrm{Ca}(\mathrm{II})$ & 100 & 0.364 & 107.1 \\
\hline $\mathrm{Ca}(\mathrm{II})+\mathrm{HPO}_{4}^{2-}$ & 100 & 0.340 & 100.0 \\
\hline $\operatorname{Mg}(\mathrm{II})$ & 10 & 0.367 & 108.0 \\
\hline $\mathrm{Zn}(\mathrm{II})$ & 10 & 0.476 & 140.0 \\
\hline $\mathrm{Zn}(\mathrm{II})+\mathrm{CN}^{-}$ & 10 & 0.340 & 100.0 \\
\hline $\mathrm{Fe}(\mathrm{II})$ & 10 & 0.388 & 114.0 \\
\hline $\mathrm{Fe}(\mathrm{II})+\mathrm{CN}^{-}$ & 10 & 0.340 & 100.0 \\
\hline $\mathrm{Cu}(\mathrm{II})$ & 1 & 0.366 & 107.7 \\
\hline $\mathrm{Cu}(\mathrm{II})+\mathrm{CN}^{-}$ & 10 & 0.340 & 100.0 \\
\hline $\mathrm{Sb}(\mathrm{III})$ & 1 & 0.315 & 92.6 \\
\hline $\mathrm{Fe}(\mathrm{III})$ & 10 & 0.395 & 116.1 \\
\hline $\begin{array}{l}\mathrm{Fe}(\mathrm{III})+\text { ascorbic } \\
\text { acid }+\mathrm{CN}^{-}\end{array}$ & 10 & 0.340 & 100.0 \\
\hline $\mathrm{NaCl}$ & 1000 & 0.340 & 100.0 \\
\hline $\mathrm{Na}_{2} \mathrm{HPO}_{4}$ & 1000 & 0.340 & 100.0 \\
\hline $\mathrm{NaHCO}_{3}$ & 1000 & 0.340 & 100.0 \\
\hline $\mathrm{Na}_{2} \mathrm{SO}_{4}$ & 1000 & 0.340 & 100.0 \\
\hline $\mathrm{CH}_{3} \mathrm{COONa}$ & 1000 & 0.340 & 100.0 \\
\hline $\mathrm{KNO}_{3}$ & 1000 & 0.340 & 100.0 \\
\hline $\mathrm{NaF}$ & 1000 & 0.340 & 100.0 \\
\hline $\mathrm{Na}_{2} \mathrm{~S}$ & 100 & 0.340 & 100.0 \\
\hline $\mathrm{NaBH}_{4}$ & 100 & 0.340 & 100.0 \\
\hline $\mathrm{NH}_{4} \mathrm{Cl}$ & 1000 & 0.340 & 100.0 \\
\hline $\mathrm{H}_{2} \mathrm{O}_{2}$ & 1000 & 0.340 & 100.0 \\
\hline Citric acid & 1000 & 0.340 & 100.0 \\
\hline Tartaric acid & 1000 & 0.340 & 100.0 \\
\hline Oxalic acid & 1000 & 0.340 & 100.0 \\
\hline Ascorbic acid & 1000 & 0.340 & 100.0 \\
\hline Uric acid & 100 & 0.357 & 105.0 \\
\hline Urea & 1000 & 0.340 & 100.0 \\
\hline Creatinine & 1000 & 0.340 & 100.0 \\
\hline Glycine & 1000 & 0.340 & 100.0 \\
\hline Glucose & 100 & 0.340 & 100.0 \\
\hline DNA & 1000 & 0.340 & 100.0 \\
\hline Vitamin $B_{1}$ & 1000 & 0.340 & 100.0 \\
\hline IDA & 1000 & 0.340 & 100.0 \\
\hline NTA & 1000 & 0.340 & 100.0 \\
\hline $\mathrm{KCN}$ & 1000 & 0.340 & 100.0 \\
\hline $\mathrm{KSCN}$ & 1000 & 0.340 & 100.0 \\
\hline
\end{tabular}

$\mathrm{Al}(\mathrm{III})$ ion, $50 \mu \mathrm{g} \mathrm{L}{ }^{-1}$; PVP, 0.15\%; pH, 9.0; MCPF, $2.0 \times 10^{-5} \mathrm{M}$ reference, MCPF solution.

solution was taken and assayed according to the standard procedure without any previous treatment. The result of applying the proposed method showed good agreement with the results obtained for the nominal amount. The recovery was determined by comparing the standard absorbance values. The recoveries of the added quantity was $98.7 \%$. This indicates that the proposed method gives accurate results.

Known amounts of aluminum were added to samples of human urine, bovine serum and tap water. The recovery was 97.2 - 104.6\% (Table 4). The proposed method would provide a new approach for many investigator to carry out aluminum analysis in medical and environmental fields.

\section{Reaction mechanism}

In order to clarify the reaction mechanism, we determined the compositions of the colored complexes: the ratio of MCPFaluminum(III) in the presence of PVP by Job's methods of 
Table 4 Assay of aluminum(III) preparation and recovery tests in pharmaceutical and biological samples

\begin{tabular}{|c|c|c|c|c|}
\hline \multirow{2}{*}{ Sample } & \multicolumn{2}{|c|}{$\begin{array}{c}\text { Amounts of } \\
\text { aluminum(III)/mg }\end{array}$} & \multirow{2}{*}{$\begin{array}{c}\text { Recovery, }{ }^{\mathrm{a}} \\
\%\end{array}$} & \multirow{2}{*}{$\mathrm{RSD}_{\%}^{\mathrm{b}}$} \\
\hline & Nominal & Proposed & & \\
\hline A & 45.0 & 44.4 & 98.7 & 2.1 \\
\hline Urine & $-^{\mathrm{c}}$ & $-^{\mathrm{c}}$ & 104.6 & 2.3 \\
\hline Serum* & $-^{c}$ & - $^{\mathrm{c}}$ & 101.9 & 1.9 \\
\hline Tap water* & -c $^{\mathrm{C}}$ & — $^{\mathrm{c}}$ & 97.2 & 1.6 \\
\hline
\end{tabular}

Sample A: aspirin aluminum (tablet).

a. $50 \mu \mathrm{g} \mathrm{L}^{-1} \mathrm{Al}(\mathrm{III})$ was taken.

b. RSD: relative standard deviation $(n=6)$.

c. Undetermined.

$* \mathrm{KCN}\left(2.0 \times 10^{-4} \mathrm{M}\right)$ was added as a masking agent.

continuous variation and by the other molar ratio method, was 2:1. Figure 3 shows these experiments.

\section{Conclusion}

A simple and highly sensitive and reproducible spectrophotometric determination for aluminum(III) was established. The sensitivity $\left(\varepsilon=1.70 \times 10^{5} 1 \mathrm{~mol}^{-1} \mathrm{~cm}^{-1}\right)$ was much greater than those using other spectrophotometric methods. The proposed method, owing to no need for solvent extraction, could be applied to assays of aluminum(III) in pharmaceutical preparations; the analytical results were satisfactory. Also, aluminum(III) in human urine, bovine serum and tap water can be determined by several devices in experiments. Results suggested that the colored complex produced was the aluminum(III)-MCPF (1:2) complex. Though further investigations and other reaction species, the proposed method should be useful for a simple and high sensitive determination of aluminum(III) by MCPF as a novel chemical probe in real samples.

\section{Acknowledgements}

The authors gratefully acknowledge Mihoyo Fujitake and Katsuhiko Minoura for MS and NMR measurements at Osaka University of Pharmaceutical Sciences.

\section{References}

1. H. H. Malluche, Nephrol. Dial. Transplant., 2002, 17, 21.

2. N. M. Roberts, A. Clough, J. P. Bellia, and J. Y. Kim, J.
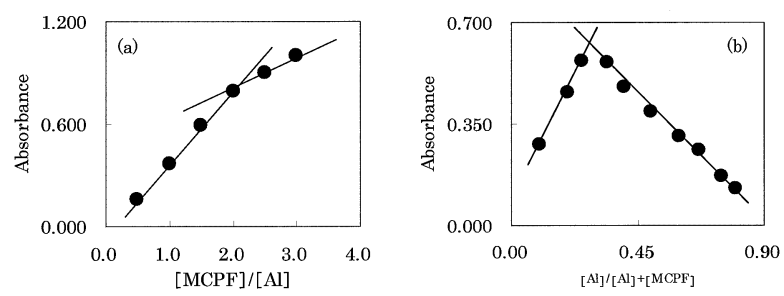

Fig. 3 Composition of the complex by the (a) mole ratio method (b) continuous variation method.

Inorg. Biochem., 1998, 69, 171.

3. P. Fattoretti, B. Freddari, M. Balietti, E. Moccheduani, J. Scancar, P. Zambenedetti, and P. Zatta, J. Alzheimers. Dis., 2003, 5, 437.

4. T. P. Flaten, A. G. Alfrey, J. D. Birchall, J. Savory, and R. A. Yokel, J. Toxicol. Environ. Health, 1996, 48, 527.

5. World Health Organization, Environmental Health Criteria 194, Aluminium, Genova: WHO, 1997.

6. A. G. Alfrey, G. R. LeGendre, and W. D. Kaehny, N. Engl. J. Med., 1976, 294, 184.

7. F. R. Alderman and H. J. Gitelman, Clin. Chem., 1980, 26, 258.

8. M. Bettinelli, U. Baroni, F. Fontana, and P. Poisetti, Analyst [London], 1985, 110, 19.

9. F. Y. Leung and A. R. Henderson, Clin. Chem., 1982, 28, 2139.

10. W. Frech, A. Cedergren, C. Cederberg, and J. Vessman, Clin. Chem., 1982, 28, 2259.

11. N. Violante, F. Petrucci, P. Delle Femmine, and S. Caroli, Microchem. J., 1992, 46, 199.

12. D. Blazejak-Ditges, Z. Anal. Chem., 1969, 246, 241.

13. Z. Marczenko and M. Jarosz, Analyst [London], 1982, 107, 1431.

14. K. Watanabe, H. Yoshizawa, and K. Kawagaki, Bunseki Kagaku, 1981, 30, 640.

15. N. M. Zolotukhina and T. M. Erenpreis, Zavodsk. Lab., 1979, 45, 257.

16. I. Mori, T. Yabuki, Y. Fujita, and T. Matsuo, Anal. Lett., 1997, 30, 953.

17. I. Mori, Y. Fujita, M. Toyoda, and K. Tanaka, Anal. Lett., 1992, 25, 2377.

18. I. Mori, Y. Fujita, M. Toyoda, and M Kashiwagi, Fresenius' Z. Anal. Chem., 1991, 340, 57.

19. Y. Fujita, I. Mori, and M. Toyoda, Anal. Sci., 1990, 6, 607.

20. C. Lieberman, Chem. Ber., 1901, 34, 2299.

21. A. Iwasa and T. Yonemoto, Bunseki Kagaku, 1992, 41, T7.

22. A. Iwasa, T. Yonemoto, I. Matsubara, and K. Nakagawa, Bunseki Kagaku, 1987, 36, T113. 